\title{
Contemporary Challenges of Empowering Women in Arab Areas in Israel from the Viewpoint of Social Workers
}

\author{
Prof. Linda fuad safoury Hisham Mustafa Yusef
}

\begin{abstract}
This study aimed at identifying the contemporary challenges of empowering women in Arab areas in Israel from the viewpoint of social workers, and to achieve the study objective; the researcher used a questionnaire consisted of (55) items divided into two fields, and it applied to a random sample consisted of (41) employees, during the first academic semester 2020/2021. The study findings showed that the degree of contemporary social challenges for empowering women in the Arab regions of Israel from the viewpoint of social workers came in a high degree, while the degree of contemporary educational challenges for empowering women in the Arab regions of Israel from the viewpoint of social workers came in a high degree.
\end{abstract}

Keywords: Contemporary Challenges, Empowering Women, Social Workers

DOI: $10.7176 /$ RHSS/11-2-02

Publication date: January $31^{\text {st }} 2021$

\subsection{Introduction}

Empowerment is vague enough to allow people to interpret it as they please, filling it with content that can be radical, objective, or simply business-as-usual? Is its wide usage due to its appearance of promoting strong action without any intrinsic policy accountability for actually doing so? Despite ongoing worries about the term and its use, empowerment continues to be a powerful concept to understand and use to advocate for social and political transformation. For example, after an extensive global debate over development priorities, the 2030 Agenda for Sustainable Development selected "Achieve gender equality and empower all women and girls" as the fifth of seventeen Sustainable Development Goals (Dworkin, Gandhi \& Passano, 2017).

What is empowerment? It is hard to substantiate the term since this question can be interpreted in various ways and will solicit different answers depending upon the contextual situation of the respondent in a larger socioeconomic setting at a given point in time. The term empowerment is often used in tandem with microfinance and is a familiar term used in the literature prepared by development agencies and apex banks. Simply stated, empowerment is usually the desired outcome of enhancing an individual's or a group's capacity to make voluntary choices, which results in favorable outcome (Ramchandani, 2017).

The term "empowerment" means the restructuring of power centers and the redistribution of power and the rights to act and make decisions. Here, the process becomes difficult and complicated at times, and needs reflection and reconsideration. The application of the concept of empowerment requires multiple changes and modifications, including behavioral, psychological, administrative, educational, and political. (Melhem, 2006). According to UNIFEM (2000), empowerment is gaining the ability to generate choices and exercise bargaining power, develop a sense of self-worth, a belief in one's ability to secure desired changes, and the right to control one's life. AlKouh (2016) explained that there is a weakness in the participation of women in union work, councils and parties, and the lack of women obtaining leadership positions in these institutions. As for economic empowerment, women still suffer from unemployment, and poor training and education. And Al-Qalla (2020) urged the most prominent social obstacles were wrong social legacies, poor family support, low educational level, and the lack of awareness of women themselves, and among the most important economic obstacles is the lack of financial independence for women. And the weak financial support provided to it by community institutions, in addition to unemployment. Moreover, Al-Karbi (2017) explained A strong relationship exists between the educational level of women and their participation in decision making and participation in various activities. However, a popular buzzword since the 1980s, there has been little informed discussion on the term 'empowerment'. As the eminent sociologist Andre Beteille wrote, most analyses around the term so far have been more context-driven than theory-driven. It is important then to look at the context in which discussions over empowerment and indeed women's empowerment have arisen. Overall, the context is one where there is a contradiction between a hierarchical social order and a democratic political system, while empowerment may be invoked in virtually any context, be it human rights, basic needs, capacity building, skill formation or overall economic security (Beteille, 1999: 590).

The idea of empowering women as a strategy for poverty alleviation has become one of the most common development issues, due to the interest of international institutions and organizations, such as the United Nations and the World Bank (Daoud, 2011). The definition of woman enablement requires participative self-development and freedom of choice (Al-Kouh, 2016). The subject of empowering women in the twenty-first century has become a hot issue around the world. Modern women are searching for equal opportunities with men and the two are competing strongly in various fields such as politics, economics and other social sectors. The results of many studies have shown that women around the world today stand on an equal footing with men; it is undeniable that 
some women are much better than men when it comes to some issues. Possible women contribute to the development of their country's economic, social and political status, and women make up about $50 \%$ of the world's population, and they represent the backbone of the development of their countries. On the other hand, according to the American Center for Leadership Women, the overall integration of women in the economic life of the state is essential for the welfare of society (Al Kaabi, 2020). ). Moreover, the most important means of empowering women is to raise women's awareness and introduce them to their political, social and economic rights through rehabilitation, training and building their capacity. And improving the skills of leadership, management, decisionmaking, planning, negotiation and communication to enable them to enter all fields of work, enlightenment of their rights guaranteed by national constitutions, laws and legislations, charters, covenants and international agreements, and activate the role of civil society organizations: (parties, associations, especially women and the media), to enhance women's political participation and to influence society and the decision-maker and change the prevailing perception towards them through intensive seminars, conferences and meetings, as well as developing an integrated strategy to qualify women to participate effectively in the political process within society and not to give up their rights, as well as adopting effective scientific programs directed to society in general to change the traditional cultural patterns that limit participation women politically, socially and economically, and get rid of some inherited customs, traditions, values, beliefs and ideas (Abu Khfila, 2016).

The twenty-first century is witness of dramatic challenges in terms of freedom and authority. The word "empowerment" glinted in academic literature after (1975). Since that time, this word has gained attention in each circle of life (Mukhtar, 2014). Moreover, there is a need to qualify women, train them to learn and use digital libraries, and empower and train them. In addition, one of the most important obstacles is the weakness in training women to use libraries and access to knowledge resources (Al-Qablan, 2010). Moreover, there is a strong inverse relationship between education and discrimination based on gender society. The higher the educational level, the lower the gender discrimination, and vice versa. There is also a positive tendency for women to support their presence in the political sphere and to eliminate discrimination based on gender (Yunus, 2014),

The correlation between a lack of female empowerment and other indicators of societal and economic underdevelopment is extremely strong and this has been widely documented in both the academic literature as well as in policy studies. The theoretical basis for this correlation is rooted in the inherent inefficiency of traditional patriarchal societies wherein the suppression of women's voices is a symptom of a deeper malaise that blocks development. It is a reflection of a backward looking traditionalism that inhibits progress on all fronts, hence, while empowering women has direct practical effects on poverty reduction, these are likely to be the tip of the iceberg. The broader effects on societal values may well be far more significant (Ramchandani, 2017). Moreover, Kazem (2016) explained that there is a need to change the common view of woman through presenting school curriculum TV programs and all media that give importance to the role of woman and support her in political life. And Majeed and Al-Khattab (2018) urged that there is a need to adopt a package of legal reforms must be implemented in a series of relevant laws and regulations simultaneously, in order to accomplish the main goal which is women's political empowerment in the light of a governing idea that collect between two interrelated aspects: the first is eradicating various legal obstacles related to women's political participation. The second is embodying in combination of taking sanctions against parties that do not adopt quota or adopting it at low rates. At the same time, offering incentives to parties that adopt women quota which exceed the minimum legal quota as well as adopted programs that support women's participation.

Thus, the empowerment of women entails their visibility and ability to make choices; such choices may challenge the established power hierarchy not only within the home, but in society as well (Kabeer, 2010). This means the agency of a positive kind that can be transformative. Given women's overall subordinate position, they can also have what Kabeer calls 'passive agency', where they take action in a situation where there is little choice. An example of this would be organizing a daughter's marriage when the decision of who the bridegroom should be is taken by the men in family. However, the positive aspects of agency constitute empowerment. This necessarily means self-awareness, commitment to change and to involve oneself in participatory endeavors through building on one's latent talents as well as developing new skills, both in the sphere of personality and in the areas of work and employment (Goyal \& Angeles, 2014), moreover, Alrakieb (2020) explained that there is a need to encourage small and medium enterprises (SMEs) on different levels of to support women's empowerment because psychological and material motives have a great effect on women empowerment. Moreover, Allahmdy (2020) explained that males are the main dominant, the woman has been encountered to deprivation of rights, infringement and racism that are all stand against the woman to acquire her lawful rights.

Therefore, after the researcher reviewed the theoretical literature related to the concept of empowering women, the researcher found that empowering women is a basic requirement for all societies that seek development, especially in light of the trend towards adopting and applying contemporary concepts of citizenship. This concept (empowering women) based on a new philosophy: that the focus of development in society must not be on men only, but on man and women. According to the great importance and benefit to society when adopting women's empowerment, the issue of women's empowerment in the Arab regions has come into question. Therefore, the 
current study came to investigate the contemporary challenges of empowering women in Arab areas in Israel from the viewpoint of social workers.

\subsection{Problem and questions of the study}

Despite Israel's interest in empowering women in all region, the researcher noticed, depending on her specialization and her work as a faculty member, the existence of some obstacles that prevent women from receiving adequate training, education and qualification, in order to optimize their employment, social and economic status, and thus improve society, and in light of the results of some previous studies that confirmed the presence of obstacles that prevent the education and rehabilitation of women, such as the study of Al-Kouh (2016), And Al-Qalla (2020), And Al-Karbi (2017), Al-Qablan (2010), Yunus (2014), Abu Khfila, (2016), Kazem (2016), Majeed and Al-Khattab (2018), Alrakieb (2020), and Allahmdy (2020), these reasons as a whole formed a strong motivation for the researcher to investigate the contemporary challenges of empowering women in Arab areas in Israel from the viewpoint of social workers. More specifically, the main question was: What are the contemporary challenges of empowering women in Arab areas in Israel from the viewpoint of social workers? The following two questions emerged from this question:

\section{Sub-questions:}

1. What are the contemporary educational challenges for empowering women in the Arab regions of Israel from the viewpoint of social workers?

2. What are the contemporary social challenges for empowering women in the Arab regions of Israel from the viewpoint of social workers?

\subsection{Importance of the study}

The importance of this study emerged from the urgent need to identify the contemporary challenges of empowering women in Arab areas in Israel from the viewpoint of social workers because of the rapid technical, social and educational changes in Israel, so the importance of this study comes from its results, and the impact of these results on those in charge of decision maker in Israel, and the importance of this study can be shown as follow:

\section{Theoretical importance:}

- Enrich the theoretical aspect regarded the contemporary challenges of empowering women in Arab areas in Israel, as the researcher hopes that the study results contribute in enriching Israel library in this field.

- This study is expected to open up new doors in the field of the contemporary challenges of empowering women, to conduct new studies to promote or deny the findings of this study.

\section{Applied practical aspect:}

- Providing a feedback about the contemporary challenges of empowering women in Arab areas in Israel from the viewpoint of social workers to decision maker.

- It hoped to benefit from the findings and recommendations of this study the researchers and those interested in empowering women.

- It hoped that this study finding help decision-makers in Israel in identifying the degree of the contemporary challenges of empowering women in Arab areas in Israel from the viewpoint of social workers, to help them in making appropriate decisions to improve the society.

\subsection{Terminology}

The study adopting identifying the following terms:

Contemporary challenges: "the problems and obstacles that society members face, now a day, in light of technical and economic development" (Al-Kaabi, 2020, 55), In this study, it is defined as the overall degree of the study tool intended for this purpose.

Empowering women: "Providing educational, training, rehabilitating and educational facilities that qualify women to participate in social and economic life effectively" (Al-Qala, 2020, 337). In this study, it is defined as the overall degree of the study tool intended for this purpose.

\subsection{Study limitations}

The results of this study are determined by the nature of the sample and the tool of the study, as follows:

- The sample: it is limited to the social workers.

- The temporal boundary: it is limited to the academic year 2020- 2021.

- Objective limit: identifying the degree of the contemporary challenges of empowering women in Arab areas in Israel from the viewpoint of social workers.

\subsection{Variables}

The study includes two dependent variables, namely:

- The degree of the contemporary educational challenges for empowering women in the Arab regions of Israel 
from the viewpoint of social workers.

- The degree of the contemporary social challenges for empowering women in the Arab regions of Israel from the viewpoint of social workers.

\section{Previous studies}

Alrakieb Study (2020) aimed to investigate the impact of supporting small and medium enterprises (SMEs) on different levels of the women's empowerment. The study used the statistical analysis that is based on secondary data obtained from "Kafala" initiative as one of the supporting agencies for SMEs in the Kingdom. The study also used qualitative approach based on interviewing 20 Saudi female entrepreneurs from different regions in the Kingdom. Findings indicated that women in Saudi Arabia are driven by psychological and material motives when establishing new business. Results also showed that supported ventures mostly contribute to the personal and economic empowerment for female entrepreneurs with a positive response exceeding $50 \%$ in all indicators. Results also showed modest evidence of the impact of SMEs on social empowerment with a positive response below the $50 \%$ in all indicators.

Allahmdy (2020) conducted a study aimed at identifying issues related to women's rights, which are major issues in Yemeni society. The study used the descriptive survey approach and the questionnaire as a tool for the study, and the results of the study showed that there are some challenges and obstacles that hinder the social empowerment of women. The challenges and obstacles hindering the woman to be socially, as well as requiring more political and legal support plus activation of all international conventions and charters. All strategies including the national strategy of woman must be well applied, as the woman is considered the other half of the community and a main part of this humanitarian entity, as males are the main dominant, the woman has been encountered to deprivation of rights, infringement and racism that are all stand against the woman to acquire her lawful rights.

Salama, Al-Qunayber, Al-Hamouleh, and Ammar (2020) conducted a study aimed at identifying the determinants of empowering rural women in Menoufia Governorate, describing the level of empowerment of rural women in the study area, and determining the degree of relative contribution of the independents. To achieve the objectives of the study, a random sample of (400) individuals was selected, and data were collected from two villages from the Monufia Governorate, namely the village of Mit Abu al-Kom, affiliated to the Tala Center, and the village of Zawiyat al-Na'ura, affiliated to the Martyrs Center, with 200 participants in each village. A questionnaire and a personal interview were used to collect data, the study showed several findings, and the most important of which are: that the level of empowerment of the respondents ranges between the medium and high category. Where about $44.5 \%$ of them fall into the medium empowerment category, while it showed that about $42 \%$ of the respondents had a high level of empowerment. The results of the analysis showed the regression and the presence of nine independent variables that contribute to explaining the variance in the level of empowerment. These variables were able to explain about $35 \%$ of the variation in the level of empowerment of rural women.

Al-Qalla (2020) conducted a study aimed at identifying the most prominent obstacles to empowering the Arab woman in Egyptian society. To achieve the aim of the study, the descriptive analysis method was used, and the researcher used the questionnaire to collect data among the individuals of the study sample. The most prominent social obstacles were wrong social legacies, poor family support, low educational level, and the lack of awareness of women themselves, and among the most important economic obstacles is the lack of financial independence for women. And the weak financial support provided to it by community institutions, in addition to unemployment.

Majeed and Al-Khattab (2018) conducted a study aimed at identifying the women's quota system in Kurdistan as an entry point to building a just society. The study used the documentary approach. And the study showed that the essence of the "quota" is the state's intervene as external power in bringing positive change for the benefit of the disadvantaged women and cultural minorities, and from the perspective that compensatory justice requires dealing differently with the different parties culturally and economically for the benefit of those deprived of them. Practicing of quotas merely, does not mean the full achievement of equality between cultural and sexual components in general, but it's a big leap towards achieving this crucial goal, since the latter necessarily requires a range of legal and non-legal mechanisms aimed at empowering women and expanding their capabilities as a whole. On the other hand, in the absence of a written Kurdistan constitution, a package of legal reforms must be implemented in a series of relevant laws and regulations simultaneously, in order to accomplish the main goal which is women's political empowerment in the light of a governing idea that collect between two interrelated aspects: the first is eradicating various legal obstacles related to women's political participation. The second is embodying in combination of taking sanctions against parties that do not adopt quota or adopting it at low rates. At the same time, offering incentives to parties that adopt women quota which exceed the minimum legal quota as well as adopted programs that support women's participation.

Al-Karbi (2017) conducted a study aimed to highlight the efforts exerted to empower the Emirati women in all fields. It also tackled the current situation of Emirati women, highlighting the gains achieved and the available opportunities, also challenges and efforts to implement supportive policies for women's empowerment, assessing 
the implementation and determining the situation to keep pace with developments. In order to achieve these objects, a historical descriptive approach based on the study of reality has been applied through available data such as local and international official statistics on Emirati women under the reign of Sheikh Khalifa, The study was divided into several main axes, covering aspects of women's empowerment, the political, economic and educational empowerment, with the analysis of the gap between gender indicators according to the latest global report of the gender gap. The most important results of the study: In a parliamentary precedent that reflects the success of UAE women, Dr. Amal Al Qubaisi, First Vice President of the UAE Federal National Council, chaired the sixth session of the Council, she is considered as first elected woman, and that reflects the success of Emirati women and their active participation in decision-making and that comes in the context of the UAE government's keenness to advance and empower male and female citizens. The experience of empowering women in the UAE is considered as a distinct experience compared to Arab countries and many foreign countries, according to national and cultural regulations. The UAE Constitution is considered as the primary reference and the main guarantor of women's rights. The importance of educating women in supporting the empowerment process at all levels has been demonstrated. A strong relationship exists between the educational level of Emirati women and their participation in decision making and participation in various activities.

The study of Abu Khfila (2016) aimed to present a perception about the methods to empower Arab women, and the study used the descriptive and analytical method, based on previous literature and statistics, and the findings showed that the most important means of empowering women is to raise women's awareness and introduce them to their political, social and economic rights through rehabilitation, training and building their capacity. And improving the skills of leadership, management, decision-making, planning, negotiation and communication to enable them to enter all fields of work, enlightenment of their rights guaranteed by national constitutions, laws and legislations, charters, covenants and international agreements, and activate the role of civil society organizations: (parties, associations, especially women and the media), to enhance women's political participation and to influence society and the decision-maker and change the prevailing perception towards them through intensive seminars, conferences and meetings, as well as developing an integrated strategy to qualify women to participate effectively in the political process within society and not to give up their rights, as well as adopting effective scientific programs directed to society in general to change the traditional cultural patterns that limit participation women politically, socially and economically, and get rid of some inherited customs, traditions, values, beliefs and ideas.

Kazem (2016) conducted a study aimed at identifying the most important obstacles facing the empowerment of Iraqi women in order to serve and develop their society, and the extent of her participation in social, economic and political life in the Iraqi community. To achieve these objectives, the researcher used social survey curriculum that aimed to study the phenomenon quantitatively and qualitatively through analyzing the phenomenon and finding out the relations between its different dimensions. The sample of 214 was chosen in a cluster random way. The research finding showed that the factors than hinder woman's empowerment are social factors, which come in the first position, economic and political as well as personal factors. The researcher recommends changing the common view of woman in the community through presenting school curriculum TV programs and all media that give importance to the role of woman and support her in political life.

Al-Kouh (2016) conducted a study aimed at identifying the main obstacles that led to the weak empowerment of the Arab woman. In order to achieve the aim of the study, the theoretical literature and previous studies that dealt with obstacles to empowering Arab women were referred to, and the most prominent social obstacles were the patriarchal culture of society, and the weakness of the role of women within social institutions, and as for the scientific empowerment of women, some specializations, professions and training are still limited to men. There is a weakness in the participation of women in union work, councils and parties, and the lack of women obtaining leadership positions in these institutions. As for economic empowerment, women still suffer from unemployment, and poor training and education.

Yunus (2014) study aimed to identify women's empowerment and parliamentary performance in light of a sample of electoral districts in Egypt. The study used the descriptive analytical method. The researcher used a questionnaire to collect data among the study sample, and personal interviews were conducted. The study sample consisted of five electoral districts in which women succeeded in voting. The results found that there are obstacles that weaken the empowerment of women to participate in political decision-making, and that there is a strong inverse relationship between education and discrimination based on gender in Egyptian society. The higher the educational level, the lower the gender discrimination, and vice versa. There is also a positive tendency for women to support their presence in the political sphere and to eliminate discrimination based on gender.

Al-Qablan (2010) conducted a study aimed at identifying digital libraries and their role in cognitive empowerment of women in the Kingdom of Saudi Arabia, and to achieve the goal of the study, the descriptive survey method and the questionnaire were used as a study tool, and a random sample of (115) women was selected, and by analyzing the data, the results showed a need to qualify women, train them to learn and use digital libraries, and empower and train them. And one of the most important obstacles is the weakness in training women to use 
libraries and access to knowledge resources.

\section{Method and procedures}

\subsection{Methodology}

This study aimed at investigating the degree of the contemporary challenges of empowering women in Arab areas in Israel from the viewpoint of social workers, so the study used the descriptive survey method, which regarded suitable for this study.

The study population consisted of all social workers who work in Arab area in Israel, and a sample consisted of (41) employees were chosen in arbitrary method.

\subsection{The Study tool}

To investigate the degree of the contemporary challenges of empowering women in Arab areas in Israel from the viewpoint of social workers, a questionnaire was developed by the researcher; the questionnaire was distributed using the WhatsApp application.

\subsection{Validity of the study tool}

To ascertain the validity of the study tool, content validity was used by viewing the questionnaire to (10) arbitrators of the faculty members who specialize in educational administration and sociology, so as to take their opinions on the content of the tool, and the adequacy of paragraphs, and the need to modify or delete any paragraph, and any comment they think it is necessary, in the light of the observations of the arbitrators, some items were modified, but no item deleted, and the researcher found that the paragraphs were correlated to their dimensions, as the agreement degree between the arbitrators reached (90\%), and this percentage is regarded suitable for the purposes of this study.

\subsection{Reliability of the study tool}

Research tool reliability was assured reliability by using the (Test- retest), and by applying it on (12) employee from outside the Research sample, and Pearson correlation coefficient was calculated, and the value of reliability coefficient was (0.83), and this is an acceptable value for the purposes of the Research.

The degree of the contemporary challenges of empowering women in Arab areas in Israel from the viewpoint of social workers was determined by dividing the degrees to three levels (high, medium, low) based on the following equation:

The highest value - the lowest value / number of levels $=(5-1) / 3=4 / 3=1.33$.

Thus it was adopted the following Criterion to determine the degree of the contemporary challenges of empowering women in Arab areas in Israel from the viewpoint of social workers:

- Low degree: represent grades between (1-2.33).

Medium degree: represent grades between (2.34- 3.67).

.( High degree of exercise: represent grades between (3.68- 5.00).

\subsection{Statistical treatment}

To answer the questions of the study the appropriate statistical methods were used as follow:

- To answer the first, second question, the averages and standard deviations were used.

\section{Study results and discussion}

Findings of the study and its discussion: The study presents the findings that reached through the respondents of the sample to their questions, as follows:

4.1. Findings related to the first question that stated: "What are the contemporary social challenges for empowering women in the Arab regions of Israel from the viewpoint of social workers?"

To answer this question, arithmetic averages and standard deviations were calculated for the contemporary social challenges for empowering women in the Arab regions of Israel from the viewpoint of social workers for the dimension as a whole, and for each of its items, and Table (1) shows that. 
Table (1): Arithmetic averages, standard deviations, and ranks of the contemporary social challenges for empowering women in the Arab regions of Israel from the viewpoint of social workers for the field in general, and for each of its paragraphs, arranged in descending order.

\begin{tabular}{|c|c|c|c|c|c|}
\hline no. & The question & $\begin{array}{l}\text { arithmetic } \\
\text { average }\end{array}$ & $\begin{array}{l}\text { standard } \\
\text { deviation }\end{array}$ & rank & degree \\
\hline 21 & $\begin{array}{l}\text { The tendencies of women towards working in } \\
\text { government jobs. }\end{array}$ & 4.35 & 0.49 & 1 & high \\
\hline 14 & $\begin{array}{l}\text { The large number of family responsibilities } \\
\text { entrusted to women. }\end{array}$ & 4.28 & 0.54 & 2 & high \\
\hline 11 & Gender inequality in wages. & 4.01 & 0.65 & 3 & high \\
\hline 20 & $\begin{array}{l}\text { Parents' tendencies towards women working in the } \\
\text { government sector. }\end{array}$ & 3.94 & 0.48 & 4 & high \\
\hline 2 & Male and female participation in her issues. & 3.89 & 0.52 & 5 & high \\
\hline 18 & $\begin{array}{l}\text { Lack of confidence in women's abilities hinders her } \\
\text { work. }\end{array}$ & 3.84 & 0.53 & 6 & high \\
\hline 26 & $\begin{array}{l}\text { Not to counter the negative thoughts inherited from } \\
\text { women. }\end{array}$ & 3.82 & 0.67 & 7 & high \\
\hline 7 & $\begin{array}{l}\text { The inherited culture about the priority of men over } \\
\text { women. }\end{array}$ & 3.76 & 0.81 & 8 & high \\
\hline 13 & Paternal role of the man. & 3.62 & 0.43 & 9 & medium \\
\hline 10 & $\begin{array}{l}\text { The social roles of women are restricted by the } \\
\text { inherited cultural controls. }\end{array}$ & 3.61 & 0.56 & 10 & medium \\
\hline 19 & The woman's own feeling of lack of independence. & 3.54 & 0.49 & 11 & medium \\
\hline 1 & $\begin{array}{l}\text { The dominant social culture constrains the role of } \\
\text { women. }\end{array}$ & 3.08 & 0.68 & 12 & medium \\
\hline 17 & $\begin{array}{l}\text { Lack of work opportunities for women and a } \\
\text { preference for men over them. }\end{array}$ & 3.06 & 0.71 & 13 & medium \\
\hline 23 & $\begin{array}{l}\text { Weak efforts to raise women's awareness of their } \\
\text { rights. }\end{array}$ & 3.06 & 0.73 & 14 & medium \\
\hline 4 & Lack of social institutions that deal with women. & 2.99 & 0.54 & 15 & medium \\
\hline 8 & $\begin{array}{l}\text { The difficulty of women's participation in social } \\
\text { work. }\end{array}$ & 2.94 & 0.73 & 16 & medium \\
\hline 5 & Weak focus of socialization institutions on women. & 2.88 & 0.39 & 17 & medium \\
\hline 25 & $\begin{array}{l}\text { Lack of respect and appreciation for the efforts of } \\
\text { women in society. }\end{array}$ & 2.85 & 0.83 & 18 & medium \\
\hline 15 & The weak role of women in civil institutions. & 2.84 & 0.42 & 19 & medium \\
\hline 6 & Society's rejection of female leaders. & 2.81 & 0.58 & 20 & medium \\
\hline 24 & Weak independence of women. & 2.76 & 0.57 & 21 & medium \\
\hline 16 & Low participation of women in union work. & 2.75 & 0.63 & 22 & medium \\
\hline 28 & $\begin{array}{l}\text { The absence of programs aimed at integrating } \\
\text { women socially. }\end{array}$ & 2.71 & 0.39 & 23 & medium \\
\hline 3 & Lack of social services provided to women. & 2.68 & 0.49 & 24 & medium \\
\hline 22 & $\begin{array}{l}\text { Weak community recognition of the } \\
\text { developmental role of women. }\end{array}$ & 2.67 & 0.54 & 25 & medium \\
\hline 27 & $\begin{array}{l}\text { Failure to highlight the direct and indirect } \\
\text { economic role for the social integration of women. }\end{array}$ & 2.61 & 0.65 & 26 & medium \\
\hline 12 & The lack of media adoption of women's problems. & 2.55 & 0.48 & 27 & medium \\
\hline 9 & $\begin{array}{l}\text { The difficulty of women's participation in political } \\
\text { action. }\end{array}$ & 2.51 & 0.52 & 28 & medium \\
\hline & \begin{tabular}{|c|} 
The whole degree \\
\end{tabular} & 3.23 & 0.29 & \multicolumn{2}{|c|}{ medium } \\
\hline
\end{tabular}

It is noted from Table (1) that the degree of contemporary social challenges for empowering women in the Arab regions of Israel from the viewpoint of social workers came in a high degree, as the arithmetic average reached (3.23) with a standard deviation (0.29).

This result means that there are many obstacles that prevent the empowerment of women, and this result may be attributed to the culture of society, legislation and laws. and Paragraph (21) came in the first rank, which states that "The tendencies of women towards working in government jobs", with a mean (4.35), and a standard deviation (0.49), this result means that women in the Arab regions of Israel prefer to work in government jobs, and this result may be attributed to the fact that government jobs have greater job security than jobs in the private sector, which 
limits the social participation and empowerment of women. Paragraph (9) which states that "The difficulty of women's participation in political action" came in the last rank, with an arithmetic mean (2.51) and a standard deviation (0.52). This result means that there is a weakness in the participation of women in political life, and this is one of the obstacles to empowering women, because they marginalize and exclude women politically.

This finding is agree with Al-Kouh (2016) findings that showed that there is a weakness in the participation of women in union work, councils and parties, and the lack of women obtaining leadership positions in these institutions. As for economic empowerment, women still suffer from unemployment, and poor training and education. And with Al-Qalla (2020) that showed that the most prominent social obstacles were wrong social legacies, poor family support, low educational level, and the lack of awareness of women themselves, and among the most important economic obstacles is the lack of financial independence for women. And the weak financial support provided to it by community institutions, in addition to unemployment. Moreover, with Al-Karbi (2017) that showed a strong relationship exists between the educational level of women and their participation in decisionmaking and participation in various activities. And with the findings of Abu Khfila (2016) study that showed the most important means of empowering women is to raise women's awareness and introduce them to their political, social and economic rights through rehabilitation, training and building their capacity, improve the skills of leadership, management, decision-making, planning, negotiation and communication to enable them to enter all fields of work, enlightenment of their rights guaranteed by national constitutions, laws and legislations, charters, covenants and international agreements, and activate the role of civil society organizations: (parties, associations, especially women and the media), to enhance women's political participation and to influence society and the decision-maker and change the prevailing perception towards them through intensive seminars, conferences and meetings, as well as developing an integrated strategy to qualify women to participate effectively in the political process within society and not to give up their rights, as well as adopting effective scientific programs directed to society in general to change the traditional cultural patterns that limit participation women politically, socially and economically, and get rid of some inherited customs, traditions, values, beliefs and ideas

4.2. Findings related to the second question that stated: "What are the contemporary educational challenges for empowering women in the Arab regions of Israel from the viewpoint of social workers?"

To answer this question, arithmetic averages and standard deviations were calculated for the contemporary educational challenges for empowering women in the Arab regions of Israel from the viewpoint of social workers for the dimension as a whole, and for each of its items, and Table (2) shows that.

Table (2): Arithmetic averages, standard deviations, and ranks of the contemporary educational challenges for empowering women in the Arab regions of Israel from the viewpoint of social workers for the field in general, and for each of its paragraphs, arranged in descending order.

\begin{tabular}{|l|l|c|c|c|c|}
\hline no. & \multicolumn{1}{|c|}{ The question } & $\begin{array}{c}\text { arithmetic } \\
\text { average }\end{array}$ & $\begin{array}{c}\text { standard } \\
\text { deviation }\end{array}$ & rank & degree \\
\hline 7 & Lack of incentives to educate women in universities. & 4.09 & 0.59 & 1 & high \\
\hline 21 & $\begin{array}{l}\text { Lack of providing adequate financial support to } \\
\text { educate married women. }\end{array}$ & 4.02 & 0.65 & 2 & high \\
\hline 18 & $\begin{array}{l}\text { Weak education of women on the decision-making } \\
\text { side. }\end{array}$ & 4.01 & 0.42 & 3 & high \\
\hline 16 & $\begin{array}{l}\text { Weak education of women in the aspect of developing } \\
\text { life skills. }\end{array}$ & 3.96 & 0.39 & 4 & high \\
\hline 25 & $\begin{array}{l}\text { Lack of training programs that teach women to access } \\
\text { information sources. }\end{array}$ & 3.96 & 0.58 & 5 & high \\
\hline 6 & $\begin{array}{l}\text { Weakness of plans aimed at educating and } \\
\text { rehabilitating women. }\end{array}$ & 3.92 & 0.36 & 6 & high \\
\hline 1 & $\begin{array}{l}\text { Weak education of women and their qualification for } \\
\text { leadership positions. }\end{array}$ & 3.89 & 0.38 & 7 & high \\
\hline 20 & $\begin{array}{l}\text { Weak education of women in the aspect of problem } \\
\text { solving. }\end{array}$ & 3.89 & 0.42 & 8 & high \\
\hline 17 & $\begin{array}{l}\text { Weak education of women regarding communication } \\
\text { skills. }\end{array}$ & 3.87 & 0.85 & 9 & high \\
\hline 24 & $\begin{array}{l}\text { The lack of educational programs aimed at } \\
\text { empowering women psychologically. }\end{array}$ & 3.85 & 0.37 & 10 & high \\
\hline 13 & $\begin{array}{l}\text { Some educational specialties are more related to } \\
\text { males. }\end{array}$ & 3.84 & 0.75 & 11 & high \\
\hline 22 & $\begin{array}{l}\text { The lack of programs aimed at educating married } \\
\text { women. }\end{array}$ & 3.83 & 0.62 & 12 \\
\hline
\end{tabular}




\begin{tabular}{|c|c|c|c|c|c|}
\hline no. & The question & $\begin{array}{l}\text { arithmetic } \\
\text { average }\end{array}$ & $\begin{array}{l}\text { standard } \\
\text { deviation }\end{array}$ & rank & degree \\
\hline 10 & The lack of centers to enlighten women technically. & 3.78 & 0.54 & 13 & high \\
\hline 19 & $\begin{array}{l}\text { Society's failure to adopt a clear strategy to advance } \\
\text { women's education. }\end{array}$ & 3.74 & 0.52 & 14 & high \\
\hline 12 & $\begin{array}{l}\text { The lack of legislation recognizes the compulsory } \\
\text { education of women. }\end{array}$ & 3.65 & 0.59 & 15 & medium \\
\hline 27 & $\begin{array}{l}\text { Not directing social workers to pay attention to } \\
\text { women's education. }\end{array}$ & 3.65 & 0.48 & 16 & medium \\
\hline 14 & $\begin{array}{l}\text { Decline in the value of women's education among } \\
\text { parents. }\end{array}$ & 3.43 & 0.56 & 17 & medium \\
\hline 9 & $\begin{array}{l}\text { The lack of specialized centers to eradicate female } \\
\text { illiteracy. }\end{array}$ & 3.28 & 0.61 & 18 & medium \\
\hline 8 & The lack of programs dedicated to educating women. & 3.21 & 0.68 & 19 & medium \\
\hline 23 & $\begin{array}{l}\text { Failure to take advantage of modern technologies in } \\
\text { educating married and dependent women. }\end{array}$ & 3.11 & 0.47 & 20 & medium \\
\hline 5 & $\begin{array}{l}\text { Community institutions do not adopt women's } \\
\text { training. }\end{array}$ & 3.06 & 0.83 & 21 & medium \\
\hline 11 & $\begin{array}{l}\text { Universities do not expand women's educational } \\
\text { opportunities. }\end{array}$ & 2.91 & 0.49 & 22 & medium \\
\hline 26 & $\begin{array}{l}\text { Lack of awareness of the importance of } \\
\text { girls 'education, especially in rural areas. }\end{array}$ & 2.69 & 0.75 & 23 & medium \\
\hline 4 & Inequality in education between the sexes. & 2.67 & 0.71 & 24 & medium \\
\hline 3 & Weak educational opportunities for women. & 2.58 & 0.36 & 25 & medium \\
\hline 2 & Weak training for women in general. & 2.57 & 0.57 & 26 & medium \\
\hline 15 & Parents' preference for educating males over females. & 2.42 & 0.48 & 27 & medium \\
\hline & The whole degree & 3.48 & 0.25 & \multicolumn{2}{|c|}{ medium } \\
\hline
\end{tabular}

It is noted from Table (2) that the degree of contemporary educational challenges for empowering women in the Arab regions of Israel from the viewpoint of social workers came in a high degree, as the arithmetic average reached (3.48) with a standard deviation $(0.25)$.

This result means there are many obstacles that prevent the empowerment of women in the field of education, and this result may be attributed to the culture of society, legislation and laws. and Paragraph (7) came in the first rank, which states that "Lack of incentives to educate women in universities", with a mean (4.09), and a standard deviation (0.59), this result means that universities in the Arab areas in Israel do not offer financial or moral incentives that encourage women to enroll in university and higher education, this weakens the role of universities in empowering women in education field.

Paragraph (15) which states that "Parents' preference for educating males over females" came in the last rank, with an arithmetic mean (2.42) and a standard deviation (0.48). This result means that the parents prefer to some extent the education of males, and this result may be attributed to the cultural legacies that still prevail among some.

This finding is agree with Kazem (2016) study findings that showed there is a need to change the common view of woman through presenting school curriculum TV programs and all media that give importance to the role of woman and support her in political life. And with Majeed and Al-Khattab (2018) study findings that showed that there is a need to adopt a package of legal reforms must be implemented in a series of relevant laws and regulations simultaneously, in order to accomplish the main goal which is women's political empowerment in the light of a governing idea that collect between two interrelated aspects: the first is eradicating various legal obstacles related to women's political participation. The second is embodying in combination of taking sanctions against parties that do not adopt quota or adopting it at low rates. At the same time, offering incentives to parties that adopt women quota which exceed the minimum legal quota as well as adopted programs that support women's participation. In addition, with Alrakieb (2020) study findings that showed that there is a need to encourage small and medium enterprises (SMEs) on different levels of to support women's empowerment because psychological and material motives have a great effect on women empowerment. Moreover, with Allahmdy (2020) study findings that showed that males are the main dominant, the woman has been encountered to deprivation of rights, infringement and racism that are all stand against the woman to acquire her lawful rights. And with Al-Karbi (2017) study findings that showed a strong relationship exists between the educational level of women and their participation in decision making and participation in various activities. Moreover, with Al-Qablan (2010) study findings that showed that there are a need to qualify women, train them to learn and use digital libraries, and empower and train them. And one of the most important obstacles is the weakness in training women to use 
libraries and access to knowledge resources. Moreover, with Yunus (2014) study findings that showed that there is a strong inverse relationship between education and discrimination on the basis of gender society. The higher the educational level, the lower the gender discrimination, and vice versa. There is also a positive tendency for women to support their presence in the political sphere and to eliminate discrimination based on gender.

\section{Recommendations and suggestions}

In the light of the findings of this study, the researcher recommends the following:

- Encouraging women to work in the private sector and develop self-enterprises in addition to government jobs by civil society organizations.

- $\quad$ Providing material support to reduce the burden of working women by the government.

- Adopting a program aimed at equal pay for both genders by the government.

- Adopting providing material and moral incentives to encourage women's education by the universities.

- Adopting Socialization institutions to provide appropriate education to develop the life skills of women, especially in the decision-making aspect.

\section{References}

Abu Khfila, Kamel (2016), the Political Empowerment of Arab Women: Reality and Cultural Determinants, Journal of Social Work, 55 (1), 459-489.

Al-Hamdi, Iman (2020), The Obstacles of Woman Empowerment Regarding Her Lawful Rights in The Republic of Yemen (A sociological study about the woman in Hadhramout Governorate), Al-Andalus Journal for Human and Social Sciences, 30 (1), 93-122.

Al-Kaabi, Siham (2020), Empowering Women: Opportunities and Challenges, Journal of Arts, Literature, Humanities and Sociology, 56 (1), 53-66.

Al-Karbi, Noura (2017), Empowering Emirati Women: A Vision of Leadership and Country Strategy, Reading and Knowledge Journal 16 (2), 63-90.

Allahmdy, E. (2020), Obstacles to women's empowerment of their legal rights in the Republic of Yemen (a sociological study of women in Hadramout governorate), Al-Andalus Journal of Human and Social Sciences, 30 (1), 93-122.

Al-Qablan, Najah (2010), Digital Libraries and their Role in the Cognitive Empowerment of Women: A Comparative Study of Women's Use of Digital Libraries in Major Cities and Remote Areas, The Twenty-First Conference: The Arab Digital Library: Arabic I: Necessity, Opportunities and Challenges, Arab Federation for Libraries and Information, and the Ministry of Culture and the Lebanese Association of Libraries.

Al-Qala, Manar (2020), Obstacles to Empowering Women in Development, Reading and Knowledge Journal, 229 (2), 333-362.

Alrakieb, Hind (2020), The Impact of Supporting Medium and Small Enterprises on the Levels of Empowering Saudi Women: Reality and Challenges (An Exploratory Study in light of 2030 Vision), Global Journal of economic \& Business (GJEB). 8(3), p486-502.

Beteille, Andre. 1999. 'Empowerment', Economic and Political Weekly, Vol. xxxiv (10 and 11) March 6-13: 589_ 597.

Daoud, Tawfiq (2011), Empowering Women: An Approach to Settlement, Journal of Aleppo University Research - Arts, Humanities and Education Series, 74 (1), 122-103.

Dworkin, S., Gandhi, M. \& Passano, p. (2017), Women's Empowerment and Global Health : A Twenty-FirstCentury Agenda. University of California press, eBook, Database: eBook Collection (EBSCOhost).

Goyal, O. \& Angeles, L. (2014), Interrogating Women's Leadership and Empowerment, Sage Publications Pvt. Ltd. 2014. eBook., Database: eBook Collection (EBSCOhost).

Kabeer, Naila. 1995. Reversed Realities: Gender Hierarchies in Development. New Delhi: Kali for Women.

Kazem, Thaer (2016), Obstacles to Empowering Women in Iraqi Society, Field Study at Al-Qadisiyah University, Babylon University Journal, 24 (2), 956-972.

Majid, Hussam and Al-Khattab, Zala (2018), the Feminist Quota System as an Entrance to Building a Just Society: A Study in the Empowerment of Kurdish Women, Journal of Political Science, 55 (1), 301-355.

Melhem, Y. (2006), Empowerment as a contemporary management concept. Yarmouk University, Irbid, Jordan.

Mukhtar, U. (2014), Obstacles in Way of Empowering Women: An Empirical Study of Pakistan. New Horizons (1992-4399). 8(1), p7-7.

Ramchandani, R. (2017), The Role of Microfinance in Women's Empowerment : A Comparative Study of Rural \& Urban Groups in India, Edition: First edition. United Kingdom : Emerald Publishing Limited. 2017. eBook., Database: eBook Collection (EBSCOhost).

Salama, Al-Qunayber, Al-Hamouleh, and Ammar (2020), determinants of empowering rural women in menoufia 
governorate, Menoufia Journal of Agricultural Economic \& Social Science, 5(1), p91-121.

The Koch, Othman (2016), Obstacles to Empowering Arab Women: A Sociological Analysis, Annals of Literature, Ain Shams, 44 (1), 263-277.

UNIFEM (2000), Progress of the world's women. New York, United Nations Development Fund for Women. Yunus, Ghada (2014), Women's Empowerment and Parliamentary Performance: A Field Study of a Sample of Electoral Districts in Egypt, the Arab Journal of Sociology, 27 (1), 102-123. 